\title{
NATIONAL AND SUB-NATIONAL OFFSHORING IMPACT ON EMPLOYMENT: AN APPLICATION TO MADRID REGION
}

\section{EL IMPACTO DEL OFFSHORING NACIONAL Y SUB-NACIONAL SOBRE EL EMPLEO: UNA APLICACIÓN A LA COMUNIDAD DE MADRID}

Tobarra Gómez, María Ángeles (Universidad de Castilla-La Mancha)

López Santiago, Luis Antonio (Universidad de Castilla-La Mancha) ${ }^{\text {*** }}$

Gómez Sanz, Nuria (Universidad de Castilla-La Mancha) ${ }^{* * *}$

Cadarso Vecina, María Ángeles (Universidad de Castilla-La Mancha) ${ }^{* * * *}$

\section{ABSTRACT}

The effect of delocalization on a national economy has been widely studied, however subnational delocalization remains as an unvisited field for researchers. This paper studies the effects of fragmentation and the subsequent localization outside or abroad on the level of industrial and services employment in Madrid region. We work with Madrid data from regional input-output tables and estimate a labour demand function using panel data. Our results show a significant and small negative effect on regional employment of intra-industrial inputs from the national economy and abroad, while imported inputs from other sectors and origins are complementary to employment, resulting in a positive net effect on employment. The increasing specialization in main activities and the use of external providers by firms have a positive impact on the employment of Madrid region.

Key words: Trade and labour market interactions, offshoring, employment, input-output tables, Madrid region. JEL: C67, F14, F16, J23, L60, L80.

\begin{abstract}
RESUMEN
Los efectos de la deslocalización a nivel nacional han sido objeto de estudio de numerosos trabajos, pero ese no es el caso de la deslocalización sub-nacional. Este artículo analiza los efectos de la fragmentación y subsiguiente localización, dentro o fuera de las fronteras nacionales, sobre el empleo en la industria y los servicios para la Comunidad de Madrid. Trabajando sobre los datos de las tablas input-output de la Comunidad de Madrid y estimando una función de demanda de trabajo con datos de panel. Según los resultados encontrados, hay un efecto negativo, pequeño en magnitud pero significativo, sobre el empleo regional de la adquisición de inputs intra-industriales nacionales o extranjeros, mientras que los inputs de
\end{abstract}

\footnotetext{
* Departamento de Análisis Económico y Finanzas, Facultad de Ciencias Económicas y Empresariales, Plaza de la Universidad 1. 02071, Albacete. MariaAngeles.Tobarra@uclm.es

** Departamento de Análisis Económico y Finanzas, Facultad de Ciencias Económicas y Empresariales, Plaza de la Universidad 1. 02071, Albacete. Luis.LSantiago@uclm.es

*** Departamento de Análisis Económico y Finanzas, Facultad de Ciencias Económicas y Empresariales, Plaza de la Universidad 1. 02071, Albacete. Nuria.Gomez@uclm.es

**** Departamento de Análisis Económico y Finanzas, Facultad de Ciencias Económicas y Empresariales, Plaza de la Universidad 1. 02071, Albacete. Angeles.Cadarso@uclm.es

Recibido: Abril de 2016. Aceptado: Junio de 2016.
} 
otros sectores y orígenes son complementarios al empleo, lo que supone un efecto generador de empleo. La creciente especialización en actividades principales y el uso de proveedores externos por parte de las empresas madrileñas tiene un efecto positivo sobre su empleo.

Palabras claves: Interacciones entre comercio y mercado laboral, offshoring, empleo, análisis input-output, Comunidad de Madrid. JEL: C67, F14, F16, J23, L60, L80.

\section{INTRODUCTION}

Offshoring is probably the fastest growing phenomenon in international trade nowadays and it reflects a fundamental change in the production process. This growth at international level in the last two decades is present in the fast development of imports for services and intermediate goods (as studied by Abraham and Taylor, 1996; Campa and Goldberg, 1997; Hummels et al., 2001; and Grossman and Helpman, 2002). The Spanish economy is not immune to this process, as intermediate imports grew by more than $76 \%$ between 1995 and 2000 (Cadarso et al., 2007).

"Make or buy" responds to a fundamental decision in industrial organization (Grossman and Helpman, 2002). Thanks to developments in the technologies of information and communications, that allow firms to transfer information and remote control processes, and to improvements in transport and reductions in obstacles to international trade, it has become increasingly usual to fragment production in several stages that can be located in plants thousands of kilometers apart. That is to say, firms specialized in particular stages of the production process (quite often those of greater added value, Gereffi et al., 2005) and externalize or buy from external suppliers the components or services they require as inputs.

These plants or suppliers are increasingly located where production becomes cheaper (mainly developing countries), either because of availability of certain production factors, or because of wages, labour qualification, legislation (environmental, tax, etc.), logistics, access to new markets, exploitation of technological externalities or economies of scale $^{1}$. Nevertheless, transaction costs cannot increase significantly, as in that case vertical integration would be a better option than the market for the firm (Williamson, 1979).

In any case, these international movements of merchandises potentially affect workers and economic policy, both in countries of origin for this offshoring and in destination countries. The existing literature has focused on studying the effects of international fragmentation of production on wage differentials and employment, total and by qualification, for manufacturing industries in developed countries (see, for example, the papers by Feenstra and Hanson, 1996, for the first case; Falk and Wolfmayr, 2008, for the second; and Hijzen et al., 2005, for the third). In this context, the aim of this paper is to study the impact of production fragmentation processes on employment by industry in Madrid region (MR). We will analyse the outsourcing and relocation of activities and intermediate purchases, both within and outside the region. We estimate a labour demand function augmented to include different offshoring measures to evaluate that effect in the period 2000-2003.

The analysis of this offshoring and, not only international, but also sub-national, relocation from a regional perspective is an original aspect of our work. Most analyses in this field use national data, as we will comment on the literature review section, but regions might become a highly interesting field of research, as they can prove to be even more vulnerable to

\footnotetext{
${ }^{1}$ Offshoring can also allow capital owners to better control the production process, as it increases labour demand elasticity by substituting some workers for others abroad (Rodrik, 1997).
} 
delocalization than countries. Not only because they are smaller and more open economies, but also because they might experience delocalization processes to other regions within the same country. This competition in terms of national outsourcing, leading to a sub-national relocation of the production processes, can become even harder than between countries, as there are fewer barriers (not only physical but also cultural, language, laws, distance, etc). Therefore, transaction costs linked to relocation will be lower between regions than countries, and this might compensate the lower production costs of developing countries. Furthermore, the higher productive specialization of regions means this potential relocation of production can generate a strong impact, as other supplying firms will follow. However, those impacts could have opposing signs depending on the region productive structure and specialization, leading to an overall small effect when national averages are calculated (see Ekholm and Hakkala, 2006).

Another original element in this paper is taking into account the offshoring and international and sub-national relocation impact on employment for the whole economy and not only the manufacturing industries, as is usual in the literature. We need to incorporate in our analyses services industries as, firstly, they employ most people in the economy and, secondly, they are the main agent in the so-called second offshoring, which focuses on qualified labour fundamentally in services compared to the offshoring of less-qualified labour of manufacturing activities (Andersson et al., 2016). In this sense, Cadarso et al. (2008b) shows how imported inputs required to export in services industries for nine EU countries grow on average well above those of manufacturing industries in 1995-2000 (9\% average in manufacturing vs. $37 \%$ in services).

The input-output frame provides information on intermediate inputs by products and origin purchased by every industry of MR. "Offshoring" means imported intermediate goods and services per unit of production purchased by firms placed in MR, coming from EU countries or the rest of the world ${ }^{2}$. Regional or national "outsourcing" means intermediate inputs bought by those firms within MR or the rest of the national economy ${ }^{3}$.

By type of product, we can distinguish: 1) intra-industry purchases, from the own industry, that reflect fragmentation and outsourcing of the main activities of firms; and 2) inter-industry purchases, that involve buying goods and services to other industries and using external suppliers. The impact on employment from manufacturing and services industries leading the fragmentation and relocation process, whether regional, national or internationally, can be very different depending on the evolution of those indexes. As reflected in the literature on this topic, we expect a negative effect on employment of more imported inputs from the own industry, especially when those purchases involve substituting goods and services that were previously produced within the industry and now are supplied from somewhere else. Nevertheless, the impact of purchases to other industries is a priori more ambiguous and requires an empirical analysis. Results in terms of employment can be

\footnotetext{
${ }^{2}$ Originally, the term "international outsourcing" was used for delocalisation outside national borders (Feenstra and Hanson, 1996), but nowadays the most employed term for that meaning is "offshoring". That is why we use in our paper "offshoring" to include imports by MR coming from other countries and "national outsourcing" for purchasing of inputs coming from other regions in Spain.

${ }^{3}$ While "offshoring" implies international purchases independently of the relationship between the buying firm and the supplier, that might be an affiliate or just have a contractual connection, the term outsourcing implies national purchases from independent firms (see Díaz-Mora and Gandoy, 2005). While these differences are important, they cannot be considered in the empirical analysis due to data limitations, so that for this study the term "regional or national outsourcing" will be indistinctly used for both firms that are either independent or subsidiary undertakings. On the other hand, these purchases do not need to reflect the closure of a production stage within the firm, as they might involve new products introduced in the market.
} 
useful to guide economic policies to adapt regions to a competitive environment that revolves around globalization.

In this paper we will review recent literature on offshoring and its employment impact (section 2), we will comment on the methodology to calculate different offshoring measures, the labour demand function and the data for the region of Madrid (section 3). We will also analyse the results for our estimations on the offshoring effect on regional employment, distinguishing by origin of the imported inputs (section 4), and we will finally sum up our main conclusions (section 5).

\section{LITERATURE REVIEW}

Although there exists a variety of names and measures, offshoring (together with delocalization, fragmentation, international outsourcing, offshore outsourcing) refers to a strategy of international competition: firms fragment production and look worldwide for cheaper locations or suppliers, keeping a certain quality level, to obtain more cost advantages.

The literature follows the same evolution as the phenomenon it studies, so it starts twenty years ago and it has particularly developed in the last fifteen years. The many studies focusing on the evolution of offshoring, for different data and countries, and its determinants are perfectly reviewed in the recent paper of Hummels et al. (2016). This literature starts with Feenstra and Hanson (1996, 1999) and it branches in studies analysing the offshoring determinants (that can be found in particular reviews of this literature as in Grossman and Rossi-Hansberg, 2006, and Díaz and Gandoy, 2007) and its evolution (Campa and Goldberg, 1997, using macroeconomic data for US, Canada, UK and Japan; and for Spain Minondo and Rubert, 2007; Díaz and Gandoy, 2005; and Gómez et al., 2006) and its effects. In this last group we basically find papers on the impact on productivity (Amiti and Wei, 2009, for the US; Girma and Görg, 2004, for the UK; or Fariñas and Martín, 2009, for Spain) and the labour market.

The literature most related to our paper is that referred to the offshoring effects on the labour market, either on labour demand or on wage differentials, particularly in countries of origin for that offshoring. Feenstra and Hanson $(1996,1999)$ began this type of study, using US data to analyze its impact on wage differentials between workers with different qualification. Their second paper is also the origin of most empirical papers like ours that study different types of offshoring according to the origin of the intermediate purchases: same industry that uses them to produce (intra-industry imports or narrow offshoring) or other sectors (inter-industry imports or difference offshoring). In the same line, Canals (2006a) analyses the role of offshoring in the increase of wage differentials in US, and Geishecker et al. (2007) for Germany, UK and Denmark. In a similar field, Falk and Koebel (2002) analyzed the possibility of replacing different types of workers with other types of inputs, including imports, for Germany; and Strauss-Kahn (2004) studied the effect from offshoring on the relative demand of qualified vs. non-qualified workers in France. Hijzen et al. (2005) performed a similar analysis for the UK, Egger and Egger (2003) for Austria, Geishecker (2005) compared Germany and Austria, Minondo and Rubert (2006) for Spanish manufacturing industry, and Ekholm and Hakkala (2008) for Sweden, Finland and Norway. More recently, this wave of studies rely on analysing wage differentials depending on the temporary versus permanent character of the workers' contracts (see Gorg and Gorlich, 2015 and Lee and lee, 2015). Similarly, González-Díaz and Gandoy (2016) study for Spain the impact of offshoring, excluding services, in the composition of employment, including the effects of immigrants and temporary employment. 
Considering different labour characteristics, Ebestein et al (2014) present evidence that globalization has put downward pressure on worker wages (real wage losses of 12 to 17 percentage points) through the reallocation of workers away from higher wage manufacturing jobs into other sectors and other occupations. On the other hand, Baumgarten, et al. (2013) show a negative cross-industry effect of offshoring on wages, however, labour developing non-routine tasks were less likely to suffer a negative wage impact due to offshoring. Complementary, Andersson et al. (2016) found that the relative demand for high-skilled labour tends to increase due to offshoring of services, while there is no statistically significant effect of inshoring per se. They also found that knowledge-intensive services such as 'computer and information services' and 'financial services' are positively associated with relative demand for skilled labour.

Our study focuses on the impact from outsourcing and offshoring on the level of employment and in this category we find the work by Falk and Wolfmayr (2008) that uses data by industry for seven EU countries in the period 1995-2000. This analysis concluded that intermediate imports from low-wage countries have a negative effect on employment, particularly on industries with lower requirements of qualification.

Egger and Egger (2005) also analysed the effect from offshoring on employment for 20 manufacturing industries in Austria in 1990-1998. Amiti and Wei (2009) calculate substitution elasticities between local workers and imported intermediate inputs for US data, and they find a complementary (positive) effect in this case. Cadarso et al. (2008a) does nevertheless find a negative impact from offshoring with destination Central and East European countries in medium-high technological industries, using data for 92 manufacturing industries in 1993-2003.

While most of those studies use macroeconomic data, it is also possible to refer to analyses with plant-level information, as Görg and Hanley (2005), that is focused on the electronic Irish industry in 1990-1995, and finds that some types of offshoring have a negative effect on employment.

All previously mentioned papers focus on manufacturing industries, as these started the delocalisation practices as part of their competitive strategies. The need for a certain degree of closeness between services suppliers and consumers (firms or individuals) limited offshoring practices in this type of sectors. However, the improvement in communications and the increasing use of ICT in services have opened new possibilities in services provision and they have become an increasing source of investment for multinationals in emerging economies (Bunyaratavej et al., 2008). The difficulty in obtaining data has limited the possibilities for its study, that has focused in calculating vertical specialization for services branches in some EU countries (Cadarso et al., 2008b), analysing the growth potential for service offshoring in Central and East European countries (Stare and Rubalcaba, 2009) or the possible positive effect of service offshoring on productivity of manufacturing firms (Amiti and Wei, 2009, for the US; Muñoz, 2007 and 2009, for Spain). Faced with the problem of data availability, Muñoz analyses foreign direct investment to reflect the offshoring dynamics. Crinò (2010) studies the effect of service offshoring on the level and skill of domestic employment for Italy, finding no effect on the level of employment but on its composition in favour of high skilled workers.

In a different line of research related to our paper, that of delocalisation at a regional level, works are even scarcer. The importance for the regional economic development of cross-border relationships, trade exchanges and foreign direct investment has been revealed by some papers, for example Cornett (2005) and Isbasoiu (2007). These articles highlight the relevance of the outsourcing, insourcing and re-outsourcing processes that are transforming 
the regional productive systems, within the general process of European economic integration. More recently, Romero et al. (2009) analyses the potential loss of internal interconnections resulting from delocalisation in the Chicago region. Within the national borders it is difficult to find references on production fragmentation, but Minondo (2003) studies a related topic: the border effect of the Basque country with the rest of Spain and other countries, without distinguishing between final and intermediate products.

The evidence on these effects from production fragmentation and subsequent relocation on the regional labour markets is even more anecdotal. We can quote Moritz (2008) about Czech regions close to Germany and Austria and changes due to the integration of that country within the EU. Using microeconomic data for workers, this author concludes that the levels of unemployment were not affected in general by the accession, but he observes a rise in wages compared to other Czech non-EU-bordering regions. Other studies, like Maggi et al. (2007), focus on employment in some activities, as logistics, that experience changes in the process of internationalization, for Italian districts in this case.

Problems are obviously different for the regions destination of delocalisation, and for those that are origin and can suffer more intensively the potential negative effects on employment. The Madrid region could be included in that second group since a decade ago. Nevertheless, there are not many empirical studies that analyse in detail the evolution of domestic, national or international delocalisation for Madrid region (MR). The exception is a study on delocalization and employment in MR (Myro et al., 2008), for 2000-2007, using their own database of manufacturing plants affected by offshoring together with results from surveys to different firms. There is, however, other studies about subcontracting at regional level for the Spanish economy as a whole (Holl, 2008) and some papers that analyze in more detail the evolution of that externalization or subcontracting for particular industries, like electronics, with a special relevance in MR (Suárez-Villa and Rama, 1996 and Rama et al., 2003).

Most papers on offshoring use data from IOT, as they provide information on intermediate purchases by industry, and they distinguish between domestic and imported inputs. This allows us to study offshoring in detail through different measures, as the increase in the trade of intermediate inputs is one of offshoring most visible consequences: the fragmentation of the production process and the geographical relocation of tasks will create the need for importing those inputs to continue the production process. Other studies measure offshoring by means of surveys or other sources of information providing data on inputs (total or distinguishing between raw materials, services, etc.) used by each industry or firm.

Using IOT has several limitations. On one hand, some of the imported intermediate goods (and services) are not related to delocalization. They are imported inputs that are not produced locally, or are related to raw materials scarce in the local economy, or simply due to the different productive specialization for each region. On the other hand, imported intermediate goods do not include all delocalization if this takes place for the whole productive process (and not only for some tasks or stages), that is to say, when the relocation is complete, or if after delocalization the resulting input is not imported. In the first case, offshoring will be reflected in an increase of final imports while intermediate imports could even decrease 4 . Another additional limitation has to do with the periodicity of IOT publication, that makes comparison difficult because of the time lag between tables, and it also provokes that the last available data usually fall far behind in time.

\footnotetext{
${ }^{4}$ This often happens, for example, in the case of clothing.
} 


\section{METHODOLOGY}

In this section we will comment on the main methodological aspects of this paper, beginning by the calculation of the offshoring and other delocalisation measures, the equation to estimate and finishing with the data we will use and the variables for production, employment and labour costs.

\subsection{Offshoring and outsourcing measures by product, region and country}

In order to measure offshoring, we start from the symmetric IOT, provided by the Statistical Institute for Madrid region (Instituto de Estadística de la Comunidad de Madrid). Those tables are available for years 1996, 2000, 2001, 2002 and 2003. Tables for years 1996, 2000 and 2002 are original while tables for 2001 and 2003 are obtained by indirect methods, but this should have relatively little impact on their validity. In our econometric analysis we chose not to include data from the 1996 table. There are two main reasons for this: first, methodological changes in the elaboration of IOT $^{5}$, and second, the 1996 IOT does not distinguish between imported purchases from EU countries and the rest of the world ${ }^{6}$.

We obtain the technical coefficients for each industry by dividing each element of those matrices of domestic and imported inputs by production $(q)^{7}$. The typical element for the domestic matrix, $d_{i j}$, shows the amount of domestic intermediate input $i\left(D_{i j}\right)$ required per euro of production in industry $j$. For the imported matrix, $m_{i j}$ shows the amount of imported input $i$ $\left(M_{i j}\right)$ required per euro of production in industry $j$. Furthermore, we use superscripts to denote imports from the rest of Spain (RS), European Union (EU) and the rest of the world (ROW) and their coefficients. We will follow Egger and Egger (2003) and Strauss-Kahn (2004) in dividing intermediate purchases by effective production ${ }^{8}$. By so doing we obtain a measure that is closer to the idea of offshoring, as we identify more accurately the tasks that firms stop performing and start purchasing in the market.

From those technical coefficients we define the sub-national (or domestic) and national (or rest of Spain, RS) outsourcing variables as intermediate purchases from each of those locations per unit of production. We use an extended definition of outsourcing, since the original definition considers outsourcing only to those purchases to firms without subsidiarity relationship (see Díaz-Mora and Gandoy, 2005). Since IOT do not allow to distinguish affiliated companies, we use outsourcing in a broader way. And similarly, EU and rest of the world (ROW) offshoring as imported intermediate goods and services originating in those countries per unit of production.

Measures used in this paper, as described below, follow the original paper by Feenstra and Hanson in that they distinguish three different types of offshoring: broad, narrow and

\footnotetext{
${ }^{5}$ Methodological changes together with structural changes render results from 1996 IOT incomparable in some cases with those from the rest of IOT, what can generate some inconsistencies.

${ }^{6}$ This disaggregation of imported inputs is done for 2000 and 2002 IOT. The 1996 table distinguishes between rest of Spain and rest of the world (with no distinction for EU imports) while the 2001 and 2003 tables only distinguish between domestic purchases and imports. This is why we have estimated the missing data on the origin for imports by assuming that the proportion of imported input by each origin in relation to the domestic inputs is constant between 2000 and 2001 and between 2002 and 2003.

${ }^{7}$ We have deflated the data for each industry by using price indices for Spain from the EU KLEMS database provided by the Groningen Growth and Development Centre for domestic products and from the rest of Spain and average price indices for EU provided by EU KLEMS for imports, using 2000 as base year.

${ }^{8}$ Hijzen et al. (2005) divide by added value, Görg and Hanley (2005) by total wages, and Feenstra and Hanson (1996) divide by total non-energy intermediate inputs.
} 
difference. The broad outsourcing and offshoring measures (Sum) for each industry are the imported intermediate inputs from all industries (in terms of IOT that corresponds to the sum of the column in the use matrix):

Broad regional outsourcing $\operatorname{Sum}_{j}^{I N T}=\sum_{i=1}^{N} \frac{D_{i j}}{q_{j}}$

Broad national outsourcing $\operatorname{Sum}_{j}^{R S}=\sum_{i=1}^{N} \frac{M_{i j}^{R S}}{q_{j}}$

Broad EU offshoring $\operatorname{Sum}_{j}^{E U}=\sum_{i=1}^{N} \frac{M_{i j}^{E U}}{q_{j}}$

Broad rest of the world offshoring Sum $\operatorname{SOW}_{j}^{\text {ROW }}=\sum_{i=1}^{N} \frac{M_{i j}^{R O W}}{q_{j}}$

A second group of measures, narrow outsourcing and offshoring (Nar), can be calculated as imported intermediate goods and services purchased from that own industry (in terms of IOT, this measure is the coefficient of the elements in the main diagonal for the use matrix). These measures would be calculated as follows:

Narrow regional outsourcing $\operatorname{Nar}_{j}^{I N T}=d_{j j}$

Narrow national outsourcing $\operatorname{Nar}_{j}^{R S}=d_{j j}^{R S}$

Narrow EU offshoring $\operatorname{Nar}_{j}^{E U}=m_{j j}^{E U}$

Narrow rest of the world offshoring $\operatorname{Nar}_{j}^{\text {ROW }}=m_{j j}^{\text {ROW }}$

The difference measure (Dif) for each industry includes imported intermediate inputs of all types of goods and services except for those coming from the same industry (in terms of IOT, that can be measured as the sum of the column in the matrix less the value of the element in the diagonal) and, as its name indicates, is the difference between the broad and the narrow measures:

Difference regional outsourcing Dif ${ }_{j}^{I N T}=\sum_{i=1}^{N} d_{i j}, \forall i \neq j$

Difference national outsourcing Dif ${ }_{j}^{R S}=\sum_{i=1}^{N} d_{i j}^{R S}, \forall i \neq j$

Difference EU offshoring Dif ${ }_{j}^{E U}=\sum_{i=1}^{N} m_{i j}^{E U}, \forall i \neq j$

Difference rest of the world offshoring Dif ${ }_{j}^{R O W}=\sum_{i=1}^{N} m_{i j}^{R O W}, \forall i \neq j$

The narrow measure seems more appropriate to describe what we call delocalization, as it reflects intra-industry links or purchases. This idea is closer to the definition of offshoring as "contracting out of activities that were previously performed within a production unit to foreign subcontractors" (Hijzen et al., 2005), and this is used in most of the mentioned papers (for example, Egger and Egger, 2003, and Hijzen et al., 2005 or more recently by Gorg and Gorlich, 2015). Nevertheless, this measure does not include some activities that, even though 
they can be originally taking place within the firm, when they are outsourced they become classified in a different industry (transport, accountancy, computing services, etc.). On the other hand, the broad measure includes purchases of intermediate inputs that could have never been produced in the considered industry (energy, raw materials). The broad measure is used, for instance, in Lee and Lee (2015), distinguishing between manufacturing and nonmanufacturing inputs. Other limitations we must mention are common to all these measures. They might include imports that are not related to offshoring because they could be linked to imported goods and services that could never be produced locally (restrictions of raw materials and other reasons). On the contrary, they might neglect part of the offshoring process when that relocation includes the whole production process or the last stage, as reimported goods would be classified as final goods.

All the data considered in this paper come from the same source, the Madrid region (MR) IOT. Data on employment, wages, production or value added were available from different sources (regional accountancy or industrial survey ${ }^{9}$ ), but by using only one source we ensure consistency in methodology and industry classification ${ }^{10}$.

TABLE 1: INTERMEDIATE GOODS PER PRODUCTION UNIT IN MR

\begin{tabular}{|l|c|c|c|c|}
\hline & $\mathbf{2 0 0 0}$ & $\mathbf{2 0 0 1}$ & $\mathbf{2 0 0 2}$ & $\mathbf{2 0 0 3}$ \\
\hline Broad regional outsourcing (SumINT) & 0.2579 & 0.2582 & 0.2679 & 0.2662 \\
\hline Broad national outsourcing (SumRS) & 0.1419 & 0.1441 & 0.1708 & 0.1708 \\
\hline Broad EU offshoring (SumEU) & 0.0375 & 0.0390 & 0.0648 & 0.0668 \\
\hline Broad rest of the world offshoring (SumROW) & 0.0138 & 0.0143 & 0.0288 & 0.0295 \\
\hline Total IIP/Q & 0.1933 & 0.1974 & 0.2644 & 0.2671 \\
\hline Total IP/Q & 0.4512 & 0.4556 & 0.5323 & 0.5333 \\
\hline
\end{tabular}

Source: Cadarso et al. (2009).

Note: IP: intermediate purchases; IIP: imported intermediate purchases (EU+RoW).

*1996 ROW IIP also include EU IPP.

The evolution of the outsourcing and offshoring variables here presented for MR was analysed in detail in a previous paper (Cadarso et al., 2009). The main conclusions can be summed up by saying that the regional data follow a pattern similar to the Spanish one, with minor exceptions (a national analysis can be found in Cadarso et al., 2008a). We highlight the increase in intermediate goods per production unit that is taking place in all sectors, independently of the origin of the goods (see Table 1). This is explained by the spread of the externalization and subcontracting as common firms strategies to obtain cost reductions, specialization and scale economies. This process is taking place more acutely in MR because industrial concentration areas induce firms' externalization and delocalization processes, mainly for the ones with smaller size (see Holl, 2008, for the precise analysis of the effect of industrial agglomerations on subcontracting; and Villa and Rama, 1996).

\footnotetext{
${ }^{9}$ As we have done for other studies for the Spanish economy (see for example Cadarso et al., 2008a).

${ }^{10}$ Other sources of information, different from those provided by INE (Spanish Statistical Institute) or the Regional Statistical Institute of Madrid, are databases provided by consulting firms or elaborated by means of the systematic study of press news. These other sources try to correct the lags and lack of detail of the statistical sources, but they have other disadvantages equally important: they might not be representative and it is very difficult to check on their methodology.
} 
Table 1 results go in line with Minondo (2003): the trade bias, explained by the common language, common trade regulations, geographical closeness and related characteristics leads to stronger trade relationships within a region and among regions in Spain. However, Table 1 also shows that international trade are becoming generalised, impelled by complex productive processes that require higher specialization, what should lead to a reduction in the domestic bias. The pattern of increase in intermediate inputs per unit of production is mainly explained by the growing use of imported inputs coming either from the rest of Spain or the rest of the world (including EU), while inputs coming from Madrid region keep at 26\% of production for the whole period.

\section{FIGURE 1: NARROW OUTSOURCING AND OFFSHORING MEASURES FOR MADRID REGION BY INPUTS ORIGIN}

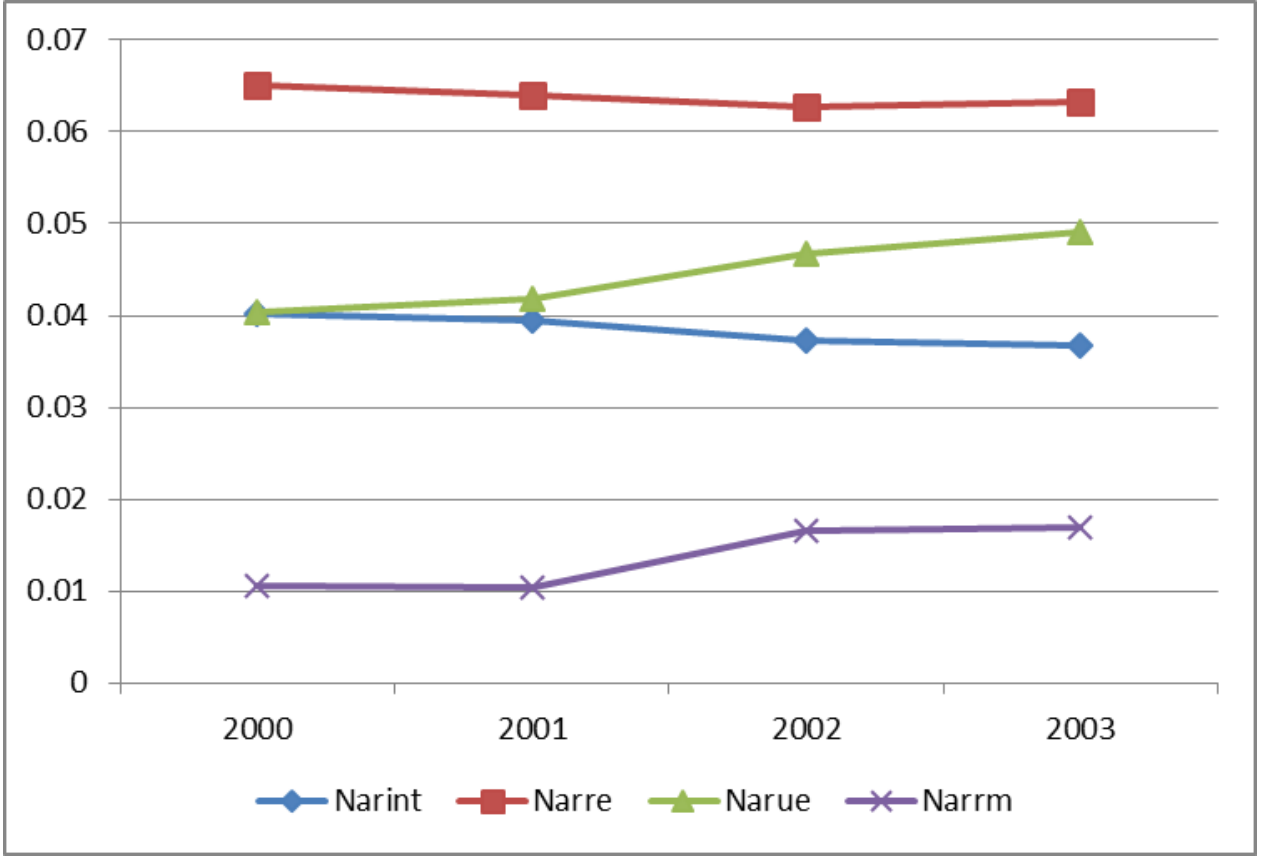

Note: Nar variables refer to narrow offshoring; and INT means domestic (regional),

RS rest of Spain, EU European Union and ROW rest of the world.

Source: Own elaboration

We expect important differences of intra and inter-industry inputs purchases on employment, so we will distinguish narrow and differences measures. Figure 1 captures the behaviour of intra-industry intermediate inputs measures (narrow outsourcing and offshoring) and shows a minor reduction of regional and national purchases for 2000-2003 while foreign purchases show a significant increase. Although intermediate inputs from EU are already three times the value of rest of the world intermediate inputs, the increase is more acute for the last group. This result points to a tendency to substitute local, regional or national intraindustry inputs for foreign ones. This tendency reveals that firms obtain more advantages from international production fragmentation, closer to intra-industrial trade, than from proximity. That is why narrow offshoring from the rest of the world is higher than regional or national narrow outsourcing. 
FIGURE 2: DIFFERENCE OUTSOURCING AND OFFSHORING FOR MADRID REGION BY ORIGIN OF INPUTS

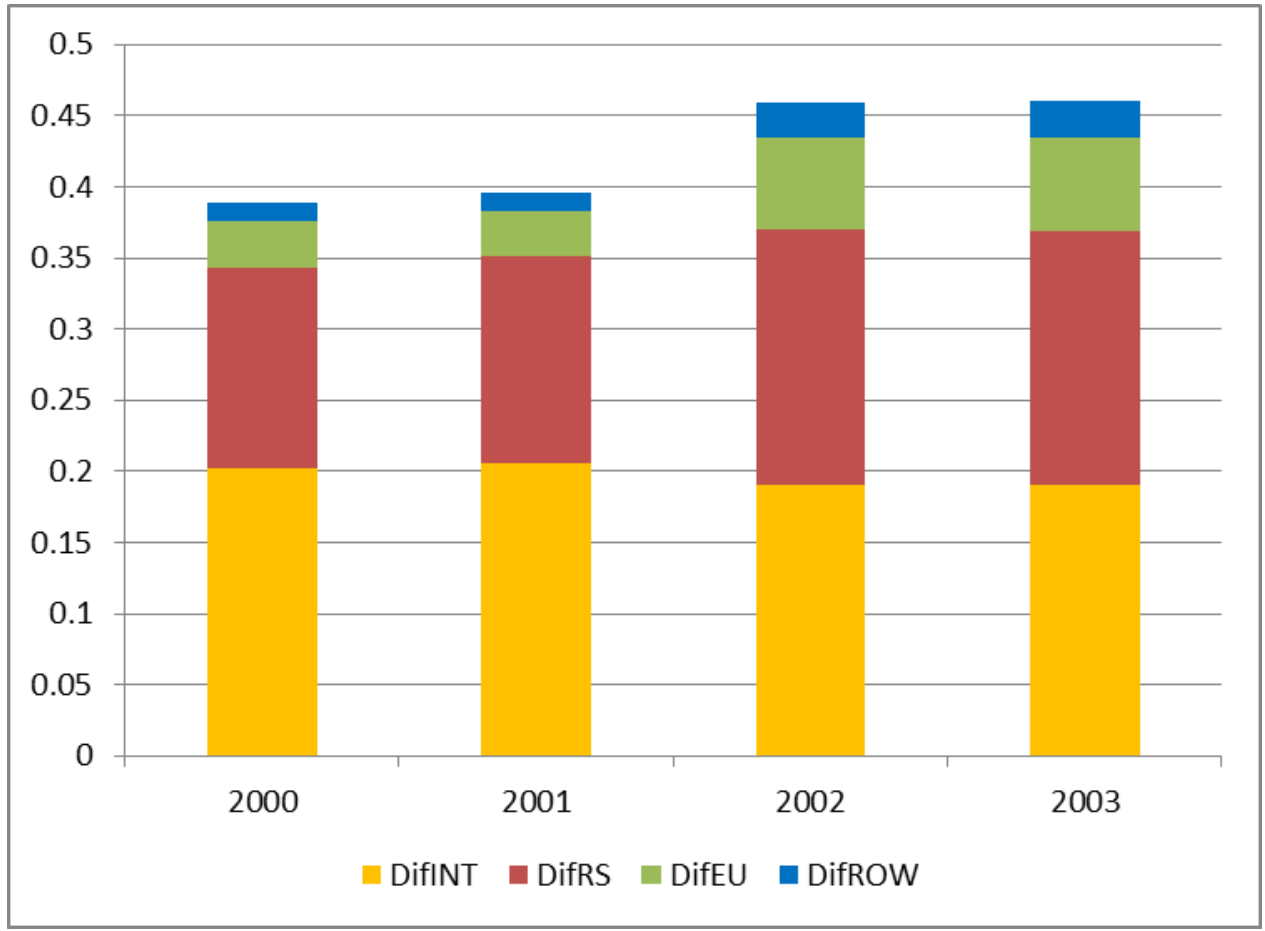

Note: Dif variables refer to difference offshoring; and INT indicates domestic (regional), RS rest of Spain, EU European Union and ROW rest of the world.

Source: Own elaboration

Inter-industry delocalisation measures (difference outsourcing and offshoring including purchases to any other sector but itself) also show an increase of imported intermediate inputs, while regional and national intermediate inputs keep the same value over the period (Figure 2). This stability can be explained by the need of geographical closeness in this type of inputs, as it is the case for some services. We can also see that sectors with higher narrow outsourcing and offshoring are those with high and high-medium technology that require very specific components in which other countries are very competitive (as shown in Figure 3 that presents narrow outsourcing and offshoring from all origins outside the MR for the start and the end of the period). These are also the same industries where international flows of foreign direct investment are particularly intense. Also the increase in narrow outsourcing and offshoring is higher as well for these industries (namely, vehicles and components, electronics, office and precision machinery, and pharmaceutical products). 


\section{FIGURE 3: NARROW OUTSOURCING AND OFFSHORING FROM ALL ORIGINS OUTSIDE THE REGION FOR THE MANUFACTURING INDUSTRY IN THE MR}

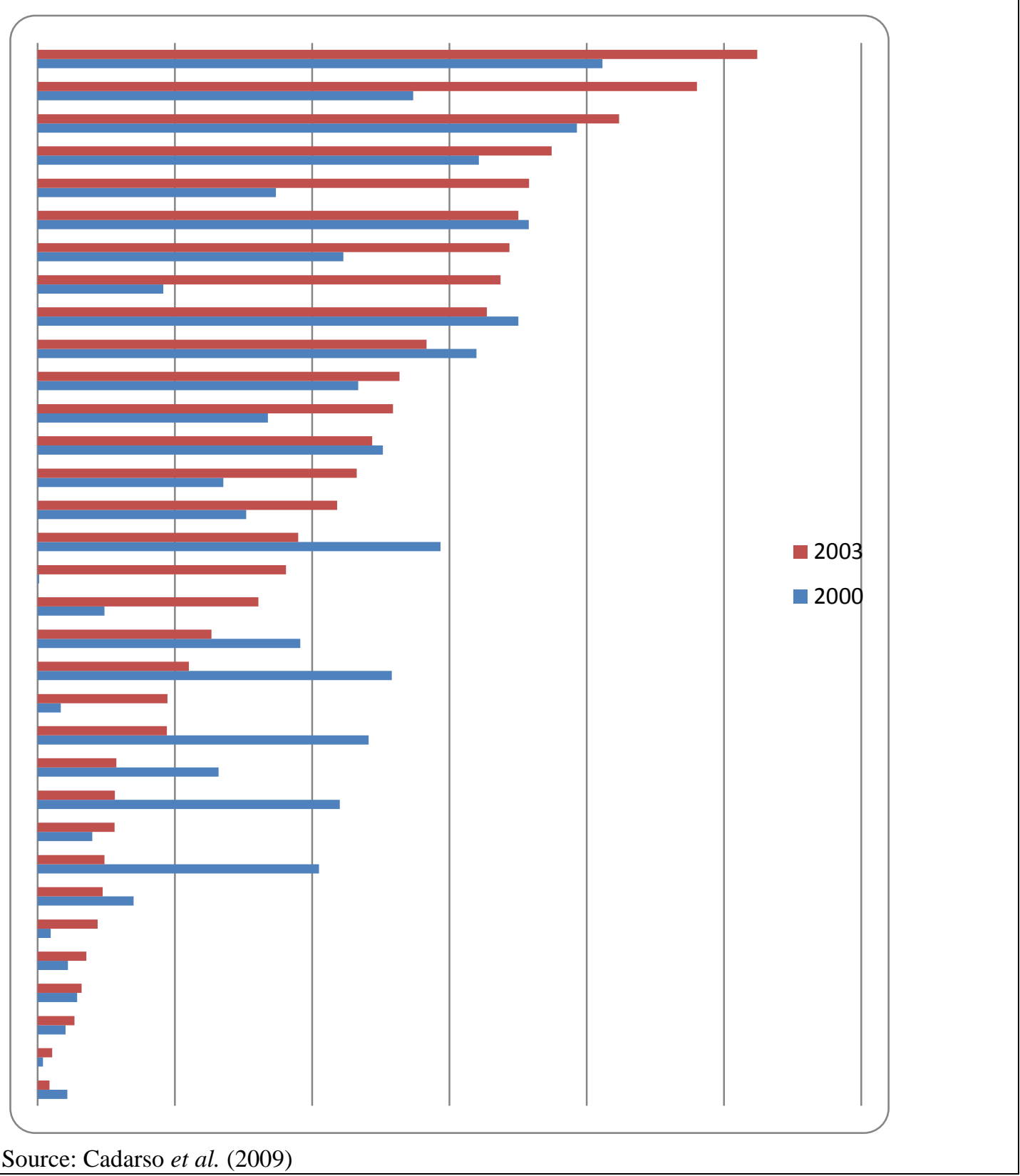

\subsection{Labour demand function and employment in the Madrid region.}

In order to study the effect of offshoring on the level of employment by industry, we will estimate a labour demand function from a CES production function, in the line of Barrell and Pain (1997), Piva and Vivarelli (2003) and Cadarso et al. (2008a). Starting from the assumption of profit-maximizing firms in a perfect competition environment, it is possible to get demand function for productive factor labour from the first order condition stating that marginal product for each factor must equal its real price (adjusted or not by some type of margin). By applying logarithms, we obtain a linear relation between employment, production, real wage (or labour cost) and other factors.

The formulation starts from a CES function like: 
$Y=A\left[(\beta K)^{-\rho}+(\alpha N)^{-\rho}\right]^{-(1 / \rho)}$

Where $Y$ is production, $K$ is capital stock, $N$ is employment, $A$ is Hicks-neutral technological change, $\alpha$ and $\beta$ are technical parameters and $0<\rho<1$. Solving the first order condition we commented above (quantity of labour input that maximises profits), taking logs and reorganizing, we obtain:

$n=y+\sigma w-(1-\sigma) \ln \alpha$

Where $\sigma=1 /(1-\rho)$ is the elasticity of substitution between $K$ and $N$, and small letters denote $\operatorname{logs}(n$ is $\log ($ employment $), y$ is $\log$ (production), $w$ is $\log ($ labour cost)).

This labour demand function can be completed by including other variables related to technical change or changes in how to produce (like offshoring), and be estimated using panel data:

$n_{i t}=\alpha_{0} y_{i t}+\alpha_{1} w_{i t}+\alpha_{2}$ offshoring ${ }_{i t}+\left(\varepsilon_{i}+u_{i t}\right)$

For $i=1, \ldots, N$ industries and $t=1, \ldots, T$ years, and where $\varepsilon$ are individual errors (time invariant) and $u$ is the usual error term. Offshoring denotes the different variables of outsourcing/offshoring under consideration. And the estimated parameters $\alpha_{j}$ will gives us the relation between our variables of interest.

There is an increase in employment for MR in the analysed period, from 2,105,591 workers (full-time equivalent wage-earners) in 2001 to 2,350,986 in 2003, reflecting the economic growth in this period. However, labour growth is basically rooted in Services' jobs. As presented in Figure 4, around $75 \%$ of the employment in this region is concentrated on services sectors, including $16.2 \%$ in the retail industry and $6.7 \%$ in public administration, as this region hosts a great part of the state administration. While employment grows in this period for all main sectors (agriculture, energy and mining, construction and services), except for manufactures, this increase is much faster in services (13\%), energy (12\%) and construction (11\%), as building and related industries were booming. In fact, while some manufactures lose employment in this period, industries like cement, forge, metallic structures and other non-metal manufactures also present important increases.

FIGURE 4: EMPLOYMENT BY MAIN INDUSTRY IN THE MR (NUMBER OF FULL-TIME EQUIVALENT WAGE-EARNERS)

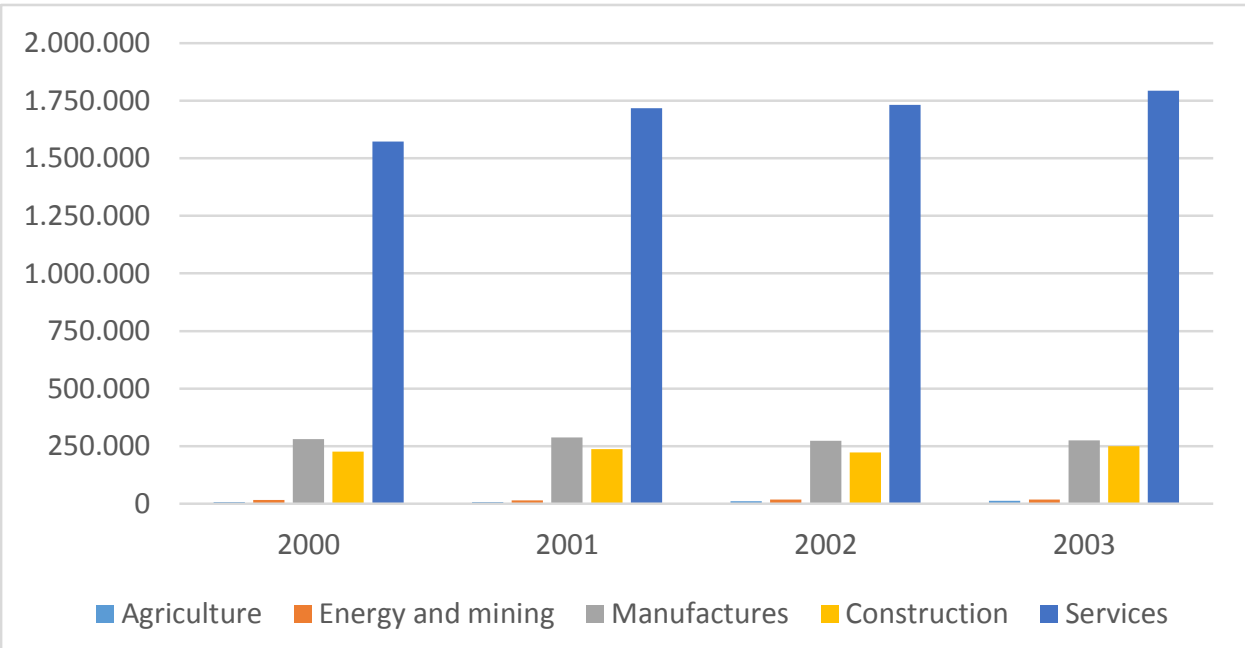

Source: Data from Input-Output tables for the MR, Madrid Statistical Office (several years) 
Also to be considered, MR enjoys a number of localisation advantages, due to both its population and market size, and to being the country's capital: many firms' headquarters are based in the capital or its nearby, and many services tend to centralise to facilitate its distribution to the whole of the country. Some disadvantages must also be mentioned, such as infrastructures' saturation, more expensive land and labour, and close regions' competence, such as Castilla-La Mancha, that competes with lower salaries and prices for most goods and services. The present analysis is concerned with the impact of delocalisation processes on industry-level employment in MR.

\subsection{Model specification}

The econometrics used in this paper is static panel data, applying OLS to a pool of data, and we also show results using fixed effects. The choice of this technique is determined by data availability (51 industries and 4 years). Panel data allow us to benefit from both industry and time dimensions for the data. As can be seen in the results, $F$ tests indicate in all cases that fixed effects are significant, so we need to model those data taking into account those industry characteristics. We also present Hausman tests that mostly support this conclusion ${ }^{11}$. Even thought we should ideally use other techniques that treat more appropriately the temporal evolution of data, as dynamic panel data (that we have used in other papers for national data, as in Cadarso et al., 2008a), there are only four years of available data. Any model using dynamic panel data would imply giving up half of the information ${ }^{12}$. The introduction of fixed effects among the regressors provides another advantage, as this chosen econometric methodology requires exogenous independent variables, and this is only the case if factors are perfectly mobile and all variables adjust automatically. Introducing fixed effects, we can control for not complying with those requisites, as the differences between sectors would be absorbed by the industry fixed effects leading to unbiased results (see Amiti and Wei, 2005).

The dependent variable is the number of full-time equivalent wage earners. Among the explanatory variables we include two fundamental factors for any labour demand function: production and labour cost. Production is measured by added value, calculated by subtracting total intermediate purchases from the value of production. This simplifies the empirical application as it renders unnecessary to introduce intermediate purchases in the equation. This element should show a significant positive effect on employment, as more workers are needed in order to obtain more added value, unless technical change takes place. The variable that shows the effect of labour cost is the ratio workers' wages / number of full-time equivalent wage earners. We expect a priori a significant negative effect from this variable on employment.

While imported inputs required for production from other industries can be complementary with domestic employment, narrow outsourcing may lead to a reduction in the amount of domestic labour. Therefore, we would expect a negative sign in our analysis from narrow outsourcing while the sign for offshoring is more difficult to predict.

\footnotetext{
${ }^{11}$ See note in Table 2 for an explanation on Hausman test.

${ }^{12}$ We have also estimated the regressions using random effects (GLS), as well as regressions in differences (as this is the closest technique to dynamic panel data), to check for robustness. These results are available to the interested reader by addressing the authors.
} 


\section{EMPIRICAL RESULTS FOR OUTSOURCING AND OFFSHORING IMPACT ON EMPLOYMENT IN THE MADRID REGION}

The main results from our estimations are shown in Table 2 . We can firstly point out that added value and labour cost variables are both significant in all cases. Their coefficients are relatively stable and they have the expected signs in our labour demand function: positive for added value and negative for wage.

In relation to our variables of interest, the different offshoring measures, we must highlight the differences between the broad measures (Sum), narrow or intra-industry (Nar) and difference or inter-industry (Dif). Intermediate purchases per unit of production for each industry (broad offshoring) show a positive and significant effect when their origin is domestic (Madrid region), the rest of Spain and other EU countries, but those coming from the rest of the world are not significant. The processes of externalizing and fragmentation of production have a positive impact on employment in the activities that lead those processes, whether they are manufacturing or services sectors. However, when we divide those broad measures into their two components (narrow and difference), we can see that aggregate behaviour is the result of a negative significant effect for the narrow measures of outsourcing and offshoring from all origins but the own MR, and a significant positive effect for the difference outsourcing and offshoring with domestic origin, rest of Spain and, to a lesser extent, EU countries. This difference in sign shows that the negative or positive effect on employment depends on the type of product, intra or inter-industry, that is subcontracted, and not so much on the origin of the intermediate good or service, that is more relevant for the level of the effect. On the other hand, the effect on employment could be different for Madrid city and the rest of its region, being the former the main urban site and the latter more rural, following conclusion from Ekholm and Hakkala (2006). Offshoring could be expected to boost employment in more urban production, taking advantage or better communications and transportation means, absorbing employment from rural areas in the nearby, however data availability restrictions does not allow to find any conclusion on this issue.

The analysis of data and the concept in which we base our outsourcing and offshoring measures lead us to expect a high degree of inverse correlation between those measures, as firms will relocate activities previously purchased from domestic suppliers to national, EU or rest of the world suppliers. The reduction of the domestic measure entails an increase of one of the other measures. This same correlation will also be observed for any other relocation. This fact advises us against including all outsourcing and offshoring measures in the same regression. 
Tobarra Gómez, Ma.A.; López Santiago, L.A.; Gómez Sanz, N.; Cadarso Vecina, Mª A.

\begin{tabular}{|c|c|c|c|c|c|c|c|c|c|c|c|c|}
\hline \multicolumn{13}{|c|}{$\begin{array}{l}\text { TABLE 2: EFFECT FROM DIFFERENT OUTSOURCING AND OFFSHORING VARIABLES ON EMPLOYMENT } \\
\text { BY INDUSTRY FOR THE MR }\end{array}$} \\
\hline & (1) & (2) & (3) & (4) & (5) & $(6)$ & (7) & (8) & (9) & (10) & (11) & (12) \\
\hline $\begin{array}{c}\text { Added } \\
\text { value }\end{array}$ & $\begin{array}{l}0.426 \\
(.063)^{* * *}\end{array}$ & $\begin{array}{l}0.474 \\
(.072)^{* * *}\end{array}$ & $\begin{array}{l}0.434 \\
(.067)^{* * *}\end{array}$ & $\begin{array}{l}0.441 \\
(.070)^{* * *}\end{array}$ & $\begin{array}{l}0.449 \\
(.066)^{* * *}\end{array}$ & $\begin{array}{l}0.500 \\
(.073)^{* * *}\end{array}$ & $\begin{array}{l}0.467 \\
(.071)^{* * *}\end{array}$ & $\begin{array}{l}0.489 \\
(.078)^{* * *}\end{array}$ & $\begin{array}{l}0.432 \\
(.063)^{* * *}\end{array}$ & $\begin{array}{l}0.452 \\
(.069)^{* * * *}\end{array}$ & $\begin{array}{l}0.433 \\
(.067)^{* * *}\end{array}$ & $\begin{array}{l}0.444 \\
(.068)^{* * *}\end{array}$ \\
\hline Wage & $\begin{array}{l}-0.175 \\
(.075)^{* *}\end{array}$ & $\begin{array}{l}-0.174 \\
(.076)^{* *}\end{array}$ & $\begin{array}{l}-0.175 \\
(.073) * *\end{array}$ & $\begin{array}{l}-0.175 \\
(.074)^{* *}\end{array}$ & $\begin{array}{l}-0.180 \\
(.082)^{* *}\end{array}$ & $\begin{array}{l}-0.187 \\
(.077)^{* *}\end{array}$ & $\begin{array}{l}-0.160 \\
(.076)^{* *}\end{array}$ & $\begin{array}{l}-0.159 \\
(.079)^{* *}\end{array}$ & $\begin{array}{l}-0.178 \\
(.071)^{* *}\end{array}$ & $\begin{array}{l}-0.185 \\
(.077)^{* *}\end{array}$ & $\begin{array}{l}-0.169 \\
(.074)^{* *}\end{array}$ & $\begin{array}{l}-0.174 \\
(.075)^{* *}\end{array}$ \\
\hline $\begin{array}{l}\text { Outsourcing } \\
\text { / Offshoring }\end{array}$ & $\begin{array}{l}\text { Sum }^{\text {INT }} \\
0.150 \\
(0.48)^{* * *}\end{array}$ & $\begin{array}{l}\text { Sum }^{\text {RS }} \\
0.121 \\
(.041)^{* * *}\end{array}$ & $\begin{array}{l}\mathbf{S u m}^{\mathbf{E U}} \\
0.039 \\
(.019)^{* *}\end{array}$ & $\begin{array}{l}\text { Sum }^{\text {ROW }} \\
0.011 \\
(.018)\end{array}$ & $\begin{array}{l}\mathbf{N a r}^{\mathbf{I N T}} \\
0.022 \\
(.012)^{*}\end{array}$ & $\begin{array}{l}\mathbf{N a r}^{\mathbf{R S}} \\
-0.002 \\
(.006)\end{array}$ & $\begin{array}{l}\mathbf{N a r}^{\mathbf{E U}} \\
-0.016 \\
(.004)^{* * *}\end{array}$ & $\begin{array}{l}\text { Nar }^{\text {ROW }} \\
-0.014 \\
(.004)^{* * *}\end{array}$ & $\begin{array}{l}\text { Dif }^{\mathbf{I N T}} \\
0.141 \\
(.044)^{* * *}\end{array}$ & $\begin{array}{l}\mathbf{D i f}^{\mathbf{R S}} \\
0.098 \\
(.030)^{* * *}\end{array}$ & $\begin{array}{l}\mathbf{D i f}^{\mathbf{E U}} \\
0.034 \\
(.016)^{* *}\end{array}$ & $\begin{array}{l}\text { Dif }^{\text {ROW }} \\
0.012 \\
(.020)\end{array}$ \\
\hline $\mathbf{R}^{2}$ & 0.878 & 0.864 & 0.849 & 0.867 & 0.850 & 0.859 & 0.853 & 0.848 & 0.886 & 0.880 & 0.854 & 0.868 \\
\hline F (FE) & $\begin{array}{l}38.03 \\
(0.000)\end{array}$ & $\begin{array}{l}37.06 \\
(0.000)\end{array}$ & $\begin{array}{l}34.75 \\
(0.000)\end{array}$ & $\begin{array}{l}33.30 \\
(0.000)\end{array}$ & $\begin{array}{l}34.88 \\
(0.000)\end{array}$ & $\begin{array}{l}34.43 \\
(0.000)\end{array}$ & $\begin{array}{l}36.95 \\
(0.000)\end{array}$ & $\begin{array}{l}36.66 \\
(0.000)\end{array}$ & $\begin{array}{l}37.78 \\
(0.000)\end{array}$ & $\begin{array}{l}37.72 \\
(0.000)\end{array}$ & $\begin{array}{l}34.95 \\
(0.000)\end{array}$ & $\begin{array}{l}32.38 \\
(0.000)\end{array}$ \\
\hline $\mathbf{F}$ & $\begin{array}{l}22.95 \\
(0.000)\end{array}$ & $\begin{array}{l}22.27 \\
(0.000)\end{array}$ & $\begin{array}{l}20.71 \\
(0.000)\end{array}$ & $\begin{array}{l}19.39 \\
(0.000)\end{array}$ & $\begin{array}{l}20.54 \\
(0.000)\end{array}$ & $\begin{array}{l}20.98 \\
(0.000)\end{array}$ & $\begin{array}{l}19.85 \\
(0.000)\end{array}$ & $\begin{array}{l}19.02 \\
(0.000)\end{array}$ & $\begin{array}{l}23.38 \\
(0.000)\end{array}$ & $\begin{array}{l}22.54 \\
(0.000)\end{array}$ & $\begin{array}{l}20.84 \\
(0.000)\end{array}$ & $\begin{array}{l}19.38 \\
(0.000)\end{array}$ \\
\hline Hausman & $\begin{array}{c}\chi 2(6)=14 \\
(.024)\end{array}$ & $\begin{array}{c}\chi 2(6)=22 \\
(.001)\end{array}$ & $\begin{array}{c}\chi 2(6)=28 \\
(.000)\end{array}$ & $\begin{array}{c}\chi 2(6)=0 \\
(.999)\end{array}$ & N/A & N/A & $\begin{array}{c}\chi 2(6)=12 \\
(.061)\end{array}$ & N/A & $\begin{array}{c}\chi 2(6)=11 \\
(.071)\end{array}$ & $\begin{array}{c}\chi 2(6)=30 \\
(.000)\end{array}$ & $\begin{array}{c}\chi 2(6)=71 \\
(.000)\end{array}$ & $\begin{array}{c}\chi 2(6)=22 \\
(.001)\end{array}$ \\
\hline \multicolumn{13}{|c|}{$\begin{array}{l}\text { All variables are in logs. T tests of coefficients show in parenthesis standard errors. } * \text { denotes significance at } 10 \% \text { level, } * * \text { at } 5 \% \text { and } * * * \text { at } 1 \% \text {. F (FE) is test of significance for } \\
\text { industry dummies in the fixed effects regressions (FE), and when significant implies rejection of the ordinary least squares (OLS) model. F is the test of joint significance for the } \\
\text { whole of the exogenous variables in the model. Hausman is a test for the RE vs. FE model (if rejected it means FE would be preferable). F, F (FE) and Hausman tests show in } \\
\text { parenthesis p-values, probability of obtaining that value for the test if the null hypothesis was true (values close to } 0 \text { imply rejecting the null). Standard errors in table are robust, as } \\
\text { heterocedasticity is observed. Time dummies have been introduced in all regressions. Number of observations is } 205 \text { ( } 51 \text { industries and } 4 \text { years) for most regressions. }\end{array}$} \\
\hline
\end{tabular}




\subsection{Intra-industry outsourcing and offshoring.}

The negative impact of narrow national outsourcing and narrow international offshoring indicates that firms in MR increasingly buy from outside the region more intra-industry inputs per unit of production at the expense of reducing direct employment. That is to say, firms substitute workers, which they previously contracted directly to perform activities that belong to the main activity of that industry, for intermediate inputs purchased to firms of the same industry located in other regions or countries. These results are similar to those of Egger and Egger (2005), Amiti and Wei (2009), Falk and Wolfmayr (2008) and Cadarso et al. (2008a) for the manufacturing industry in different countries using estimations of a labour demand function, and Myro et al. (2008) for manufactures in $\mathrm{MR}^{13}$. The difference of this paper is that we extend that negative impact to the whole economy (including services) and not only imports from abroad, but also from other regions.

The value for intra-industry coefficients in the estimations shows that the negative impact of national and international externalization on employment is small. The reduction of employment linked to EU (-0.014 coefficient) and rest of the world offshoring $(-0.016)$ are greater than that related to national outsourcing $(-0.002)$. This means that the employment destruction is more accentuated when fragmentation is relocated abroad than when it goes to other Spanish region. Nevertheless, these coefficients are below the offshoring coefficient for the Spanish economy in 1995-2000 by Cadarso et al. (2008a), -0.059. MR would seem to be stronger than the Spanish average in this sense.

Globalization has generated a new competitive environment, where most industries can find a supplier at international scale, which can provide them with intra-industry intermediate goods and services allowing them to substitute activities that were previously performed by their own workers. From textile, shoes or electronics firms that nowadays import from China, India or Morocco those merchandises they previously produced and they now focus on design, innovation and distribution, to phone companies that contract phone customer services in Tangiers, or business services firms that subcontract software consultancy services abroad or financial firms that operate with other financial firms abroad, affiliates or not. A lot of those business and distribution services exhibit the characteristics required for their relocation and provision from abroad (Bardhan and Kroll, 2003): no face-to-face required, high information content, possibility for working on the net, high wages differential between countries, low barriers, etc.

Intra-industry purchases within the same region do not show a significant impact on employment, as it also happened for the papers using national data. This can be partly explained by the disaggregation level of data, as those intra-industry purchases that take place within the region are included in the employment measure, their outsourcing reduces employment within the firm but increases intra-industry employment in the region, so we do not expect a negative sign.

\footnotetext{
${ }^{13}$ Myro et al. (2008), from own data on manufacturing plants affected by offshoring together with results from surveys to different firms, find that the negative effects of offshoring on employment in the MR is concentrated on the following manufactures: Textile and clothing, Leather and shoes, Chemical industry, Electrical, electronic and optical material, Vehicles and Other transport material.
} 


\subsection{Inter-industry outsourcing and offshoring.}

The impact on employment from purchases to other industries is a priori more ambiguous, as these might be the result of outsourcing (subcontract) activities that were previously performed within the firm but when acquired from other firm they become classified in a different industry. The typical example is that of services activities (accountancy, cleaning, software development) in manufacturing firms that when outsourced become classified in services industries. They can also be products that were purchased from some firms and now they are demanded from suppliers located in other regions or countries. In this case the direct impact on employment should be insignificant.

In any case, and whatever the direct impact on employment by industry, we should take into account the existence of indirect effects. The most important would be the effect derived from potential increases in competitiveness and productivity resulting from gaining access to intermediate goods of better quality and/or price (see Amiti and Wei, 2009, where services offshoring has a positive impact on productivity for US manufactures; or Girma and Görg, 2004, that find a positive effect on productivity for UK manufactures; or Fariñas and Marcos, 2009 , for Spain, that also links higher productivity levels with offshoring, but changes the sign of causality). Starting from the assumption that substituting some suppliers by others allows firms to reduce costs or incorporate technical improvements in products, an indirect effect could be the increase (or non-decrease) of sales in competition situations of competitiveness and improvement in the firm's especialization. This would be positive for its competitiveness, market share and employment.

Our estimations show that a higher intermediate inputs consumption has an important positive effect on employment for different industries in the MR. The positive impact on employment of inter-industry outsourcing and offshoring variables is much higher than the negative impact of intra-industry purchases. This is why, when estimating coefficients for the broad outsourcing and offshoring variables, which include both types of purchases, the impact was positive. The final result we observe is a positive effect on employment, with a similar level to the negative impact for wages. Cost savings, due to wages and specialization, which allow for outsourcing and increasingly indirect production, create employment in those industries, at the same time that wage increases mean a reduction of direct employment.

The advantages brought to the MR industries by fragmentation and outsourcing in terms of employment are greater the closer are the firms that provide inputs. The coefficients in our estimations are higher when the intermediate purchases come from within the region and the rest of Spain, than when they come from abroad. These results are consistent with the data, as the share of inter-industry purchases from the region and the rest of Spain is in 2003 far greater than for imports: $36.8 \%$ for regional and national vs. $9.2 \%$ for imports. Nevertheless, imported inter-industry purchases more than double between 2000 and 2003, while regional and national only grow by $7 \%$ (Cadarso et al., 2009).

Lower transaction costs linked to physical proximity ${ }^{14}$ to regional and national firms to which Madrid firms subcontract inter-industry or secondary activities, and their competitiveness, seem to be more important than the cost reductions provided by offshoring to low-wage countries. This physical proximity is important when outsourcing noncharacteristic or secondary tasks, but not so much when outsourcing main tasks or activities to other firms in the same industry, as the effect from the intra-industry measure was greater for

\footnotetext{
${ }^{14}$ These results are consistent with papers like Bottazzi and Peri (2003) and Moreno et al. (2006), who highlight the importance of physical distance in the transmission of knowledge between economic agents to create patents.
} 
imports. That is to say, their knowledge of the production process allows firms to look for a competitive supplier at worldwide scale, while in secondary activities the lack of information and the peculiarities of that task lead them to contract a local or Spanish provider.

\section{CONCLUSIONS}

Offshoring as the fragmentation of production processes or tasks that are located around the world is one of the fast growing phenomena in the last years. Its study at regional level is scarce, even though regions may be more vulnerable. In MR, the increase of inputs from outside the region has reached 116\% between 1996 and 2000 (higher than for the Spanish economy, $76.5 \%$ between 1995 and 2000) and $67.7 \%$ between 2000 and 2003. By estimating a labour demand function augmented to include inter and intra-industry outsourcing and offshoring, we have analysed the impact of fragmentation and relocation on employment by industry in MR.

Intra-industry outsourcing and offshoring show a negative although small effect on employment for MR. This impact is greater for imports per unit of production when they come from the rest of the world, followed by those from EU countries and finally from the rest of Spain, while it is not significant for purchases within the region. Madrid firms in different industries can find suppliers at worldwide level to obtain inputs that they previously produced and were part of what can be considered their main activity. These imports save direct employment in these industries, both manufacturing and services. However, the small value of coefficients suggests that the negative impact of international fragmentation processes is, in these years, limited in terms of employment.

Inter-industry intermediate purchases within the same region, from the rest of Spain and even from abroad have an important positive effect on employment in MR. These purchases include raw materials, components, consultancy services, transport, financial or social services. Substituting some input suppliers for others or outsourcing some secondary activities allow firms to reduce costs or incorporate technical improvements in products that will benefit employment. Furthermore, the effect on employment increases with proximity between supplier and buyer. The advantages from that closeness and the competitiveness of those suppliers justify these results.

The negative impact on employment from intra-industry national outsourcing and offshoring is very small and is well exceeded by the positive effect from specialization and intermediate purchases from other industries. The result is a positive net impact for broad outsourcing and offshoring measures, that makes clear the advantages from specializing in main tasks for each industry. For that reason, policies must pursue that firms become capable to properly design their business project so that they focus in main activities where added value is high. Firms need to search for the best supplier of intermediate inputs at international scale and increasingly outsource secondary activities (related to accountancy, tax consultancy, logistics or financial services). Not only because, as we have seen, this specialization has a positive impact on industries that intensively buy inputs in the market, but also because it will contribute to hold a business structure capable to face a more globalised competitive environment.

MR offers advantages to firms for reaching outsourcing agreements, especially to small firms, as it presents high firm concentration, where communication channels among firms are well developed, and there are qualified workers to implement this type of project. Even so, policies should focus on those small firms with more difficulties to access the international markets for goods, services and factors. 


\section{BIBLIOGRAPHY}

Abraham, K. and Taylor, S. (1996): "Firm's Use of Outside Contractors: Theory and Evidence", Journal of Labour Economics, nº. 14, pp. 394-424.

Amiti, M. and Wei, S.J. (2005): "Fear of service outsourcing: Is it justified?", Economic Policy, n 20, pp. 308-347.

Amiti. M. and Wei, S.J. (2009): "Service Offshoring and Productivity: Evidence from the US”, The World Economy, no 32, pp. 203-220.

Andersson, L., Karpaty, P. and Savsin, S. (2016): "Labour Demand, Offshoring and Inshoring: Evidence from Swedish Firm-level Data", World Economy, doi: 10.1111/twec.12396.Bardhan, A. D. and Kroll, C. (2003), "The New Wave of Outsourcing”, Fisher Centre Research Report, 1103, University of California.

Barrell, R. and Pain, N. (1997): "Foreign Direct Investment, Technological Change, and Economic Growth Within Europe", The Economic Journal, November, nº. 107, pp. 1770-86.

Baumgarten, D., Geishecker, I. and Görg, H. (2013): "Offshoring, tasks and the skill-wage pattern" European Economic Review, n 61, pp. 132-152.

Bottazi, L. and Peri, G. (2003):“Innovation and spillovers in regions: evidence from European patent data", European Economic Review, n 47, pp. 687-710.

Bunyaratavej, K. Hahn, E.D., and Doh, J.P. (2008): "Multinational investment and host country development: Location efficiencies for services offshoring", Journal of World Business nº 43, pp. 227-242.

Cadarso, M.A.; López, L.A. and Tobarra, M.A. (2007): "El papel de las multinacionales en la deslocalización y la especialización vertical de la industria española", Revista de Economía Mundial, $\mathrm{n}^{\mathrm{o}}$ 16, pp. 27-55.

Cadarso, M.A., Gómez, N., López, L.A. and Tobarra, M.A. (2008a): “The EU enlargement and the impact of outsourcing on industrial employment in Spain, 1993-2003", Structural Change and Economic dynamics, ${ }^{\circ}$. 19, pp. 95-108.

Cadarso, M.A., Gómez, N., López, L.A. and Tobarra, M.A. (2008b): "Especialización vertical en la industria y los servicios: convergencia en la Unión Europea", Revista de estudios empresariales, segunda época, $\mathrm{n}^{\circ} 1$, pp. 65-87.

Cadarso, M.A.; Gómez, N.; López, L.A. and Tobarra, M.A. (2009): "Deslocalización a nivel regional: El caso de la industria y los servicios en la Comunidad de Madrid", Papeles de Europa, $\mathrm{n}^{\circ} .18$, pp. 93-120.

Campa, J. and Goldberg, L.S. (1997): "The evolving external orientation of manufacturing industries: evidence from four countries", NBER working paper $\mathrm{n}^{\circ} 5919$.

Canals, C. (2006a): "What Explains the Widening Wage Gap?: Outsourcing vs. Technology", Documento de Trabajo La Caixa, $\mathrm{n}^{\circ} 1$.

Canals, C. (2006b): "Offshoring y deslocalización: nuevas tendencias de la economía internacional", Documento de Trabajo La Caixa, no 3 .

Cornett, A.P. (2005): "Economic integration in a cross border perspective: An emerging new system of production", presented at 45 European Congress of the Regional Science Association, Amsterdam.

Crinò, R. (2010): Employment effects of service offshoring: Evidence from matched firms, Economics Letters $\mathrm{n}^{\circ} 107$, pp. 253-256

Díaz-Mora, C. (2008): "What Factors Determine the Outsourcing Intensity? A Dynamic Panel Data Approach for manufacturing industries", Applied Economics, n 40, pp. 2509-2521. 
Díaz-Mora, C. and Gandoy, R. (2005): "Outsourcing en la industria manufacturera española: nuevas estrategias para el nuevo siglo", Economía Industrial, nº. 358, pp. 65-77.

Díaz-Mora, C. and Gandoy, R. (2007): "El offshoring en la industria española: una revisión de la evidencia empírica”, Información Comercial Española, Revista de Economía, n $^{\circ} .837$, pp. 195-210.

Ebestein et al (2014): "Estimating the Impact of Trade and Offshoring on American Workers using the Current Population Surveys", The Review of Economic and Statistics, n. 96, pp. 581-595.

Egger, H. and Egger, P. (2003): "Outsourcing and skill-specific employment in a small economy: Austria after the fall of the iron curtain", Oxford Economic Papers, n". 55, pp. 625643.

Egger, H. and Egger, P. (2005): "Labour market effects of outsourcing under industrial interdependence", International Review of Economics and Finance, $\mathrm{n}^{\circ}$ 14, pp. 349-363.

Egger, P., Pfaffermayr, M. and Weber, A. (2003): "Sectoral adjustment of employment: The impact of outsourcing and trade at the micro level", Journal of Applied Econometrics $\mathrm{n}^{\mathbf{0}} 22$, pp. 559-580.

Ekholm, K. and K. Hakkala (2006): "The Effect of Offshoring on Labor Demand: Evidence from Sweden", CEPR Working Paper nº 5648.

Ekholm, K. and Hakkala, K. (2008): "International production networks in the Nordic/Baltic region"; OECD Trade policy working papers, $\mathrm{n}^{\circ} .61$.

Falk, M. and Koebel, B.M., (2002): "Outsourcing, Imports and Labour Demand", Scandinavian Journal of Economics, $\mathrm{n}^{\circ}$ 104, pp. 567-586.

Falk, P. and Wolfmayr, Y. (2008): "Services and materials outsourcing to low-wage countries and employment: Empirical evidence from EU countries", Structural Change and Economic Dynamics, n 19, pp. 38-52.

Fariñas, J. C. and Martín Marco, A., (2009): "Innovaciones organizativas y productividad: el caso del outsourcing internaciona", Investigaciones Regionales, $\mathrm{n}^{\circ}$ 15, pp. 251-275

Feenstra, R.C. and Hanson, G.H. (1996): "Globalization, Outsourcing, and Wage Inequality", American Economic Review, nº. 86, pp. 240-245.

Feenstra, R.C. and Hanson, G.H. (1999): "The impact of outsourcing and high-technology capital on wages: Estimates for the United States, 1979-1990", Quarterly Journal of Economics, $\mathrm{n}^{\circ} 114$, pp. 907-940.

Geishecker, I. (2002): "Outsourcing and the demand for low-skilled labour in German manufacturing: new evidence", DIW Discussion paper n 313, Berlín.

Geishecker, I. (2005): "Does Outsourcing to Central and Eastern Europe really threaten manual workers' jobs in Germany?", presented at the Workshop on Re-location of production and jobs to CEE countries-who gains and who loses organized by Hamburg Institute of International Economics and Vienna University of Economics and Business Administration.

Geishecker, I.; Görg, H. and Munch, J.R. (2007): "Do labour market institutions matter? Micro-level wage effects of international outsourcing in three European countries", Review of World Economics, n $^{\circ} 146$, pp. 179-198.

Girma, S. and Görg, H. (2004): "Outsourcing, foreign ownership, and productivity: evidence from UK establishment-level data", Review of International Economics, $\mathrm{n}^{\mathrm{o}}$ 12, pp. 817-832. 
Gómez, N., López, L.A. and Tobarra, M.A. (2006): "Pautas de deslocalización de la industria española en el entorno europeo (1995-2000): la competencia de los países de bajos salarios", Boletín Económico de Información Comercial Española, no 2884, pp. 25-42.

González-Díaz, B. and Gandoy, R. (2016): "Offshoring and employment in the EU periphery: the case of Spain", Applied Economics, n 48, pp. 1255-1270.

Görg, H. and Görlich, D. (2015): "Offshoring, wages and job security of temporary workers", Review of World Economics, n 151, pp. 533-554, doi: 10.1007/s10290-015-0220-2

Görg, H. and Hanley, A. (2005): "Labour demand effects of international outsourcing Evidence from plant level data", International Review of Economics and Finance, $\mathrm{n}^{\circ} 14$, pp. 365-376.

Grossman, G.M. and Helpman, E. (2002): "Integration versus Outsourcing in Industry Equilibrium", Quarterly Journal of Economics, n 117, pp. 85-120.

Grossman, G.M. and Hansberg, R. E. (2006): "The Rise of Offshoring: It's Not More Wine for Cloth Anymore", paper in the Symposium The New Economic Geography: Effects and Policy Implications, Jackson Hole, Wyoming.

Guillén, M. F. (2004): "La internacionalización de las empresas españolas", Información Comercial Española. Revista de Economía, nº 812, pp. 211- 224.

Hijzen, A., Görg, H. and Hine, R.C. (2005): "International outsourcing and the skill structure of labour demand in the United Kingdom”, Economic Journal, n 115, pp. 860-878.

Holl, A. (2008): "Production subcontracting and location", Regional Science and Urban Economics, n 38, pp. 299-309.

Hummels, D., Ishii, J. and Yi, K. (2001): "The nature and groth of vertical specialization in world trade", Journal of International Economics, n ${ }^{\circ}$ 54, pp. 75-96.

Hummels, D., Munch, J. and Xiang, C. (2016): "Offshoring and Labor Markets", IZA, Discussion Papers $n^{\circ} 9741$.

Isbasoiu, G. M. (2007): "Industrial clusters and regional development. The case of Timisoara and Montebelluna", MPRA paper, $\mathrm{n}^{\circ} 5037$.

Jorgenson, D. W. (2001): "Information technology and the U.S. economy", American Economic Review, no 91, pp. 1-32.

Lee, H. and Lee, J. (2015): The impact of offshoring on temporary workers: evidence on wages from South Korea, Review of World Economics, $\mathrm{n}^{\mathrm{o}}$ 151, pp. 555-587, doi $10.1007 / \mathrm{s} 10290-015-0215-\mathrm{Z}$

Maggi, E.; Mariotti, I. and Boscacci, F. (2007): "The indirect effects of manufacturing internationalization on logistics: evidence from the Italian districts", Economics and statistics discussion paper, $\mathrm{n}^{\circ}$ 31/07, Università degli Studi del Molise.

Martí, M. A. and Puertas, R. (2005): “Constituye China una amenaza para la industria tradicional española?, Economía Industrial, no 355/356, pp. 56-96.

Minondo, A. (2003), "Comercio Internacional y Efecto Frontera en el País Vasco", Revista de Economía Aplicada, no 32, pp. 115-131.

Minondo, A. and Rubert, G. (2001): "La evolución del outsourcing en el sector manufacturero", Información Comercial Española. Boletín Económico, nº 2709, pp. 11-19.

Minondo, A. and Rubert, G. (2006): "The Effect of Outsourcing on the Demand for Skills in Spanish Manufacturing Industry", Applied Economics Letters, nº 13, pp. 599-604. 
Moreno, R., Paci, R. and Usai, S. (2006): "Importancia de la proximidad geográfica y tecnológica en la difusión de la innovación: Las regiones europeas", Papeles de Economía Española, no 107 , pp. 96-115.

Moritz, M. (2011): "Spatial effects of open borders on the Czech Labour Market", Economics of Transition, $\mathrm{n}^{\mathrm{o}}$ 19, pp. 305-331.

Muñoz Guarasa, M. (2007), "Are Foreign Firms Delocalising Services from Spain”, The Service Industries Journal, n 27, pp. 305-320.

Muñoz Guarasa, M. (2009), “Inversión, desinversión extranjera y deslocalización”, Papeles de Europa, ${ }^{\circ} 18$, pp. 68-92.

Myro, R. and Fernández-Otheo, C. M. (2004): "La deslocalización de empresas en España. La atracción de la Europa central y oriental”, Información Comercial Española. Revista de Economía, $\mathrm{n}^{\circ}$ 818, pp. 185-201.

Myro, R. and Gandoy, R. (2003): «Sector industrial», en José Luis García Delgado (ed), Lecciones de Economía Española, Thomson Civitas, Madrid.

Myro, R., Fernández-Otheo, C. M., Labrador Salas, L., Baides Tudela, A.B., Álvarez López, M.E., Vega Crespo, J, Domínguez Bigador, D. and González Álvarez, J.M, (2008): "Deslocalización y empleo en la Comunidad de Madrid", mimeo, Fundación Instituto Universitario de Investigación José Ortega y Gasset and Comunidad de Madrid.

Pilat, D. and Lee, F.C. (2001): "Productivity Growth in ICT-Producing and ICT-Using Industries: A Source of Growth Differentials in the OECD?”, STI Working Papers 2001/4.

Piva, M. and Vivarelli, M. (2003): "Innovation and employment: Evidence from Italian microdata", Discussion paper 730, IZA (Forschungsinstitut zur Zukunft der Arbeit, Institute for the Study of Labour).

Rama, R., Ferguson, D. and Melero, A., (2003): "Subcontracting networks in industrial districts: The electronics industries of Madrid", Regional Studies, n 37, pp. 71-88.

Romero, I., Dietzenbacher, E. and Hewings, J. D. (2009): "Fragmentation and Complexity: Analyzing Sctructural Change in the Chicago Regional Economy", Revista de Economia Mundial, $\mathrm{n}^{\mathrm{o}} 23$, pp. 263-282.

Ruiz, T. (2005): "Grandes grupos empresariales en la industria tradicional española", Economía Industrial, n 355/356, pp. 107-131.

Stare, M and Rubalcaba, L. (2009), "International Outsourcing of Services: What Role for Central and East European Countries?", Emerging Markets Finance \& Trade, n 45, pp. 3146.

Strauss-Kahn, V. (2004): "The role of globalization in the within-industry shift away from unskilled workers in France", in Baldwin, R.E. and Winters, A.L. (eds.). Challenges to globalization: Analyzing the economics, Chicago: University of Chicago Press, pp. 209-31.

Suárez-Villa and Rama, r., (1996): "Outsourcing, R\&D and the pattern of intra-metropolitan location: The electronics industries of Madrid", Urban Studies, no 33, pp. 1155-1197.

Torrent, L. and Gual, J. (2005): "El riesgo de deslocalización industrial en España ante la ampliación de la Unión Europea”, Papeles de economía española, nº 103, pp. 173-186.

Williamson, O.E. (1979): "Transaction-Cost Economics: The Governance of Contractual Relations", Journal of Law and Economics, $\mathrm{n}^{\circ}$ 22, pp. 233-261. 